\title{
Reticuloendothelial Cell in the Bone Marrow and Its Relationship to Iron Metabolism
}

\author{
Shigeo Kariyone and Takeo Miyake \\ Department of Internal Medicine (Prof. G. Wakisaka), \\ Faculty of Medicine, Kyoto University, Kyoto
}

\begin{abstract}
Qualitative and quantitative observations of stainable iron in the bone marrow reticulum cell and in the sideroblast were performed in various hematological disorders of human subjects.

Histological and metabolic studies of iron in reticulum cells of the liver, spleen and bone marrow after the administration of colloidal iron and Mohr's salt were carried out in rabbits under various experimental conditions.

1) Hemosiderin granules in the bone marrow reticulum cell varied in various hematological disorders, not only in their amount, but also in their form and nature.

2) There was a moderate correlation between the number of iron granules in the bone marrow reticulum cell and in sideroblasts. Both of them were well correlated to the ability of erythropoiesis.

3) In animal experiments, stainable iron in the reticulum cell of the liver, spleen and bone marrow were markedly increased 4 hours after the injection of colloidal iron. After that, iron in the cell was re-distributed to other tissues according to the various experimental conditions. When a large dose of Mohr's salt was injected, iron was taken chiefly by the parenchymal cell of the liver, and then it was eluted to plasma and saturated transferrin for several hours.

Kinetics of hemosiderin iron in the reticulum cell was studied under various experimental conditions.

4) From the study of the hemosiderin turnover in reticulum cells, it was suggested that there might be a functional difference between the reticulum cell of the spleen and of the bone marrow.

5) The frequency of phagocytosis of erythroblasts and erythrocytes in the bone marrow reticulum cell was studied in clinical cases and in experimental animals, and its significance was discussed.
\end{abstract}

It is considered that the iron metabolism is closely connected with the reticuloendothelial function. However, there are very few observations concerning the role of the reticuloendothelial system (RES) in the liver, spleen and bone marrow on the iron metabolism or on the red cell production and destruction. This investigation is designed to clarify the relationship between RES function

Received for publication, February 9, 1966.

This paper was delivered at the 5th General Meeting of the Japan Society of the Reticuloendothelial System, April 11, 1965 in Fukuoka. 
and iron metabolism, especially the behavior of the reticulum cell in the bone marrow which is located closely to the sites of erythropoietic cells. The relationship between them is discussed from the results of clinical observations and animal experiments.

\section{CLINICAL OBSERVATIONS}

1. Hemosiderin granules in the bone marrow reticulum cell of human subjects

The size and form of hemosiderin granules in the bone marrow reticulum cells of normal subjects and of patients with various hematological disorders were investigated. In normal subjects, the size of most of the granules in the cell was smaller than $0.85 \mu$, but $10-20 \%$ of them were larger, up to $1.70 \mu$. The number of the granules in each reticulum cell was 12.5 on the average. In the reticulum cell of pernicious anemia, almost all granules were very fine and below $0.85 \mu$. Their average number was 43.1 , showing vigorous intake of iron in the reticulum cell due to the phagocytic action of incomplete erythroblast.

In the bone marrow of hypoplastic anemia, the granules were sometimes larger than $1.70 \mu$. The larger granules were seen as an irregular-shaped aggregated or cohered mass. The average number of the granules in each reticulum cell was markedly increased with a range of 37 to 44.4. These iron granules may be regarded as a storage iron. Some of the reticulum cells in hypoplastic anemia were stained diffusely light blue, suggesting that very fine granules reacted to iron staining.

In the cases of hereditary spherocytosis, the size of the granules was sometimes larger than $3.4 \mu$, and their forms showed marked irregularity. The average number of the granules was 51.8 to 69.0 . Diffuse blue stain of the cell was also often observed. In this disease, elevation of serum iron followed increased hemolysis, which resulted in iron deposition in the reticulum cell. Increased iron turnover by an abnormal rise of erythropoiesis and accelerated phagocytosis of erythrocyte and erythroblasts seemed to be causes of the above results.

In cases of iron deficiency anemia, only a few fine granules could be seen. Marked diffuse blue staining in the reticulum cell was also observed in a case of refractory anemia showing a disturbance of hemosiderin formation.

2. The relationship between iron contents of sideroblast and reticulum cell in the bone marrow

The average number of the granules in sideroblast and the score of the size of the granules which was divided into 3 classes were multiplied mutually; the product was assumed to indicate the amount of non-hemin iron in sideroblast. In regard to the bone marrow reticulum cell, the score for the size of hemosiderin granules which was divided into 6 classes, was multiplied by the number of the granules in individual cells. The obtained value was assumed to indicate the 


\begin{tabular}{|c|c|c|c|c|c|c|c|c|c|c|c|}
\hline \multirow{3}{*}{ 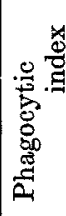 } & & โฉq० L & $\underset{\sigma}{\infty}$ & is & $\begin{array}{ll}10 \\
\text { m }\end{array}$ & $\stackrel{\leftrightarrow}{\oplus} \stackrel{-}{-}$ & $\stackrel{\varphi}{-}$ & $\stackrel{\infty}{0}$ & $\stackrel{9}{-}$ & $=$ & $\dddot{\leftrightarrow}$ \\
\hline & \multicolumn{2}{|c|}{ 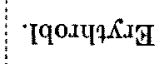 } & $\stackrel{\rho}{-i}$ & חִ & $\stackrel{\infty}{\infty}$ & $\stackrel{\oplus}{0}=\stackrel{0}{-} \stackrel{0}{-}$ & $\stackrel{10}{9}$ & $\stackrel{\leftrightarrow}{\theta}$ & $\stackrel{m}{\theta}$ & $\stackrel{\infty}{0}$ & 00 \\
\hline & & गЯみ & $\stackrel{\varphi}{-i}$ & $\stackrel{0}{0} \stackrel{0}{-}$ & $=$ in & 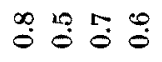 & ت & $\stackrel{10}{0}$ & $\ddot{0}$ & $\stackrel{\infty}{0}$ & $\ddot{\theta} \ddot{0}$ \\
\hline \multirow{8}{*}{ 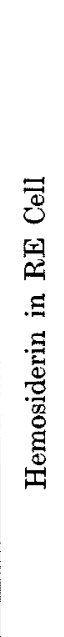 } & \multirow{7}{*}{ 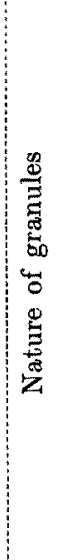 } & 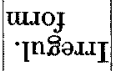 & 1 & $+\neq$ & $\neq+$ & 1111 & 1 & 1 & $H$ & + & 11 \\
\hline & & 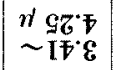 & 0 & 00 & -0 & 0000 & 0 & 0 & 0 & 0 & 00 \\
\hline & & $\begin{array}{l}n \\
\sim 9 \sigma^{\circ} \\
\sim 96\end{array}$ & 0 & 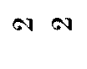 & $\rightarrow-$ & 10000 & 0 & 0 & $\infty$ & 0 & 00 \\
\hline & & $\begin{array}{l}n g g^{\circ} \\
\sim \mathrm{IL}\end{array}$ & 0 & 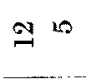 & 200 & 0000 & 0 & $\infty$ & $=$ & $\infty$ & 00 \\
\hline & & $\begin{array}{l}w_{0 L} \mathrm{I} \\
\sim 98^{\circ} 0\end{array}$ & $\infty$ & N & $\stackrel{\circ}{=}$ & $0 \infty 00$ & 0 & $\stackrel{\varphi}{\bullet}$ & $\widehat{్}$ & 5 & 9 \\
\hline & & $\begin{array}{l}n g 8^{\circ} 0 \\
\sim 80^{\circ}\end{array}$ & 5 & 28 & $\pm S$ & $\S 500$ & $\underline{\Omega}$ & $\infty$ & ib & 8 & $\infty \begin{array}{ll}\infty & \infty\end{array}$ \\
\hline & & $\operatorname{Ioquan} \mathbf{N}$ & $\ddot{9}$ & 苟是 & $\stackrel{0}{g} \dot{B}$ & $\stackrel{10}{0} \stackrel{\text { वै }}{0} 0$ & $\stackrel{n}{=}$ & $\underset{0}{\sigma}$ & $\stackrel{\infty}{\infty}$ & $\ddot{m}$ & ô \\
\hline & $\begin{array}{l}\text { ule } \\
\text { an }\end{array}$ & eqs & t & $H H$ & $H+H$ & 1111 & 1 & 1 & + & 1 & 11 \\
\hline \multirow{8}{*}{ 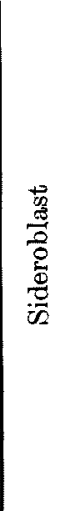 } & \multicolumn{2}{|c|}{ 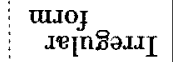 } & 1 & $+t$ & 11 & $\begin{array}{llll}1 & 1 & 1 & 1\end{array}$ & 1 & 1 & $H$ & $H$ & 11 \\
\hline & & eZIS & $\neq$ & $\neq \neq$ & $\neq \neq$ & $1+111$ & +1 & + & $\neq$ & $\neq$ & ++ \\
\hline & \multicolumn{2}{|c|}{ 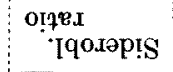 } & $\ddot{0}$ & $\Rightarrow \stackrel{0}{-1}$ & $\stackrel{\theta}{*}$ & $0 \overrightarrow{0} 00$ & 0 & 0 & $\stackrel{19}{i}$ & 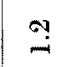 & $\stackrel{9}{\dddot{F}} \stackrel{20}{0}$ \\
\hline & \multicolumn{2}{|c|}{$\begin{array}{l}\text { qunoo } \\
\text { əลิย. } \partial \Lambda \mathrm{V}\end{array}$} & 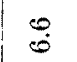 & $\stackrel{0}{0}$ & $0_{0} 9$ & $0 \stackrel{0}{-} 0$ & $\stackrel{\text { of }}{-1}$ & 0 & סקי & $\stackrel{0}{0}$ & $\underset{\sigma}{0} \stackrel{8}{8}$ \\
\hline & \multirow{3}{*}{ 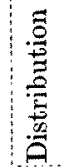 } & $\infty$ & ชิำ & $\stackrel{9}{2}+$ & $\infty \cong$ & 0000 & 0 & 0 & 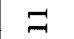 & $\infty$ & 00 \\
\hline & & 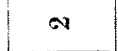 & 요 & न बै & 太心 & 0000 & 0 & 0 & 周 & లి & \\
\hline & & -1 & \pm & $\sigma 0$ & $\cong=$ & $0 \oplus 00$ & $\stackrel{9}{-1}$ & 0 & s & ติ & 조요 \\
\hline & \multicolumn{2}{|c|}{ de } & $\infty$ & $\mathscr{8}$ & 85 & $0 \underset{1}{\infty}=0$ & $\stackrel{\Omega}{N}$ & 0 & $\infty$ & 융 & 品 㤐 \\
\hline & \multicolumn{2}{|l|}{ 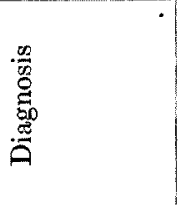 } & 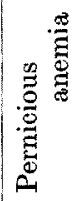 & 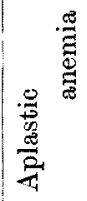 & 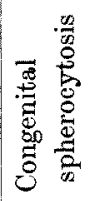 & 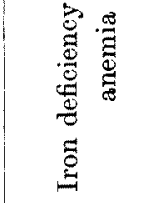 & 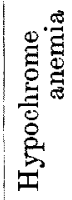 & 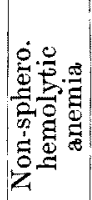 & 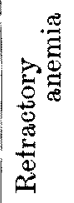 & 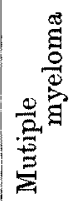 & 己 \\
\hline & & xas & 40 & to of & $\leqslant 0 \leqslant 0$ & of of of of & of & ot & of & of & to of \\
\hline & & ours $\mathbb{N}$ & ت & نَ & $\dot{0}$ & $\begin{array}{lll}\dot{E} & 0 \\
\dot{A} & \dot{\Omega}\end{array}$ & Ei & 至 & $\dot{\mathscr{H}}$ & $\stackrel{\circ}{\rightleftarrows}$ & $\begin{array}{l}\vec{q}_{1} \varepsilon \\
\dot{0} \theta\end{array}$ \\
\hline
\end{tabular}


amount of iron in the reticulum cell. Between both values there was a moderate positive correlation (Fig. 1). However, this correlation seemed to mean an indirect relation presumably between the amount of storage iron and the ability of erythropoiesis.

The relationship between radioiron utilization rate after the injection of ${ }^{59} \mathrm{Fe}$ and the amount of iron in sideroblasts or reticulum cells in the bone marrow showed a definite correlation.

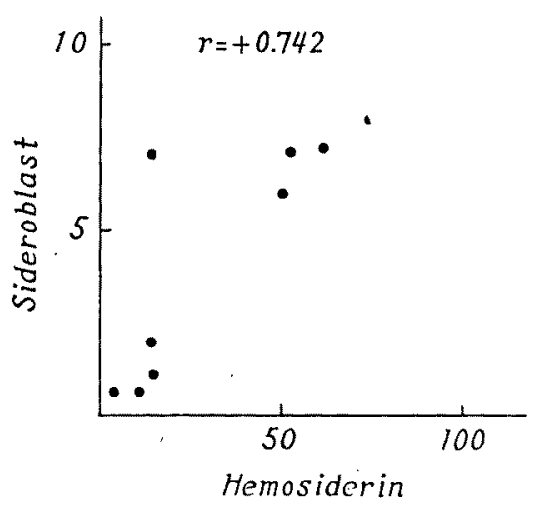

Fig. 1. Relationship between hemosiderin in RE cell and sideroblast.

\section{Phagocytosis of erythrocyte and erythroblast into the bone marrow reticulum cell}

Erythrocyte or erythroblast phagocytosis was often seen in reticulum cells of the bone marrow. The average number of erythroblast or erythrocyte which was phagocytized in a reticulum cell was expressed as the phagocytic index. In normal cases, the index had a value of 0.1 to 0.3 as shown in the table. In pernicious anemia, the indices were 1.6 for mature erythrocytes, 1.0 for erythroblasts and 2.6 for the total. From the results, the existence of the bone marrow hemolysis in this disease was suggested. High phagocytic indices were also recognized in the cases of hypoplastic anemia, congenital spherocytosis and iron deficiency anemia. The significant correlation between the amount of iron in the reticulum cell and the phagocytic index was observed.

\section{Conclusion}

In the clinical observations described above, the amount of iron in the bone marrow reticulum cell is closely related to the ability of erythropoiesis, and also it is partially associated with the phagocytosis of erythrocytes and erythroblasts into the reticulum cell in various hematological diseases. A dynamic study on the iron metabolism in the reticulum cells of the bone marrow is required to justify these conclusions. 


\section{ANTMAL EXPERIMENTS}

In order to study the iron metabolism in the bone marrow cells, especially its relation to the reticulum cells and erythroblasts, a large dose of iron was injected to rabbits with or without hematological disorders.

\section{MATERIALS AND METHODS}

Male rabbits of $2 \mathrm{~kg}$ in body weight were divided into two groups. The first group received chondroitin sulfate iron labeled with ${ }^{59} \mathrm{Fe}$ which was administered in a dose containing $20 \mathrm{mg}$ of iron per $\mathrm{kg}$ body weight. The second group received Mohr's salt (ferrous ammonium sulfate) labeled with ${ }^{59} \mathrm{Fe}$. In order to recognize the reticulum cell, $2 \mathrm{ml}$ of $4 \%$ Lithion carmine were injected to each rabbit daily during 3 days (Fig. 2). Both groups were subdivided into 6 groups according to the following treatments.

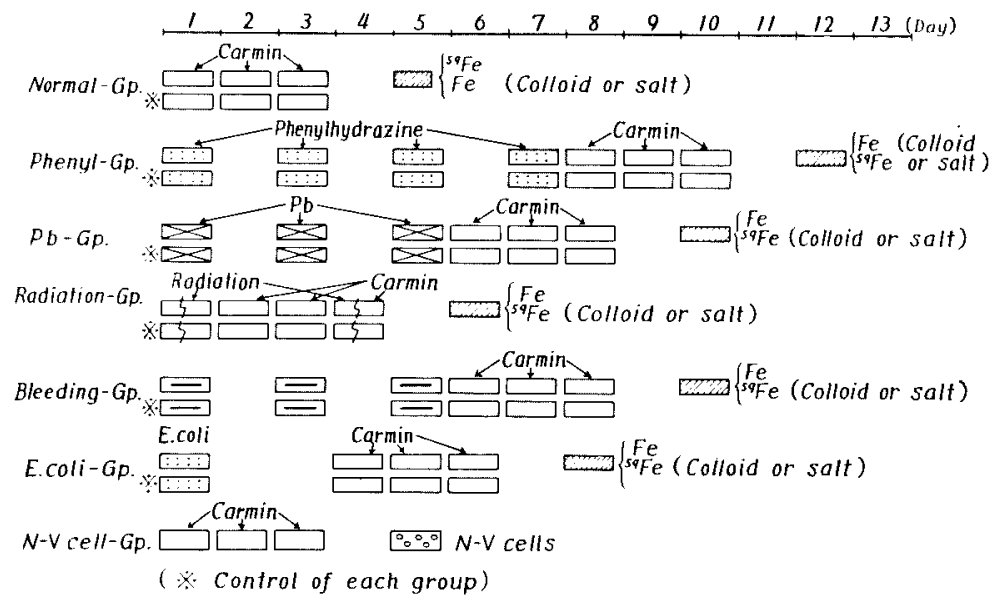

Fig. 2. Plan of animal experiments.

a) Control: The iron preparations were administered 48 hours after the last carmine injection.

b) Hemolysis by phenylhydrazine: 1\% phenylhydrazine solution was injected into each rabbit, in a dose of $0.5 \mathrm{ml} / \mathrm{kg}, 4$ times every two days.

c) Lead poisoning: Neutral lead acetate $(2 \mathrm{mg} \mathrm{Pb} / \mathrm{ml})$ was injected in a dose containing $1 \mathrm{mg} \mathrm{Pb} / \mathrm{kg}$, every two days, 3 times.

d) X-ray irradiation: The rabbits were irradiated with $300 \mathrm{R}$ of $\mathrm{x}$-ray (190 $\mathrm{KVP}, 24 \mathrm{~mA}, 1.0 \mathrm{Cu}+0.5 \mathrm{Al}$, SSD $65 \mathrm{~cm} 40 \mathrm{R} / \mathrm{min}$.) as a whole body irradiation, 2 times at 4 days' interval.

e) E. coli treated: E. coli in a suspension of $1 \mathrm{mg} / \mathrm{ml}$ was incubated in $1 \%$ formalin solution at $37^{\circ}$ for 24 hours, $1 \mathrm{ml}$ of the solution was injected 
intravenously to rabbits.

f) Bleeding: $20 \mathrm{ml}$ of the blood were taken from rabbits by heart puncture 3 times, every two days.

After the injection of iron, rabbits in every group were sacrificed at 4,24 and 120 hour intervals. The samples of blood, bone marrow, lymphnodes of intestine, spleen, liver and lung were taken, ${ }^{59} \mathrm{Fe}$ activity of these organs was measured, and iron stain was made by Kaplan's method ${ }^{1}$ on the stamp preparations.

Amount of stainable iron in the reticulum cell: Hemosiderin granules were observed by microscopy under a magnification of $\times 1000$ with oil immersion. The average numbers were calculated from 10 reticulum cells in the bone marrow and the sizes of the granules were estimated by the maximum diameter using a micrometer. The sizes were scored with a number from 1 to 6 corresponding to every $0.85 \mu$ interval. Then the total amount of stainable iron was expressed as follows:

Total amount of iron $=$ Number of the granules $\sum_{n=1}^{6} \times \operatorname{Pn}(n=$ score of the size; Pn=percentage of each class).

Amount of tissue iron: Histological findings of bone marrow, liver, spleen, lymphnodes were observed by prussian blue staining methods and ordinary H-E stain. The amount of tissue iron consisting of intracellular and extracellular iron of the reticulum cell was divided into 8 classes. $(0,0.25,0.5,0.75,1.0,2.0,3.0$ and 4.0$)$.

Phagocytosis of erythrocytes and erythroblasts by the reticulum cell: Phagocytosis of erythrocytes or erythroblasts by the reticulum cell in stamp preparation with hematoxylin nuclear stain was observed. Phagocytic indices were defined as follows: 1-2 erythrocytes in the cell $(+), 3-4(++)$, above $5(+++)$.

\section{RESULTS}

Control or non-treated rabbits: Colloidal iron clearance from the circulation $\mathrm{T} 1 / 2$ was within $40-70 \mathrm{~min}$. In the bone marrow, iron granules in the reticulum cell were 115-128, their sizes were small and almost $90 \%$ of them were below $0.85 \mu$ at 4 hours after the injection. The number of the granules decreased gradually according to the time course as well as the ${ }^{59} \mathrm{Fe}$ activity (Figs. 3 and 4 ). However, the size of the granules became larger and 3 to 4 granules, on the average, were seen in a cell at 240 hours. In the spleen, the radioactivity per unit weight and the number of iron granules in the reticulum cell were higher than those in the bone marrow. In the liver, ${ }^{59} \mathrm{Fe}$ activities were higher than those in the bone marrow at 4 and 24 hours, and stainable iron in the Kupffer cells was markedly observed.

In the cases of Mohr's salt injection, the movement of radioiron and iron granules were slow, but they showed a similar pattern in the bone marrow to that in the case of colloidal iron injection. But the amount of iron in the reticulum 


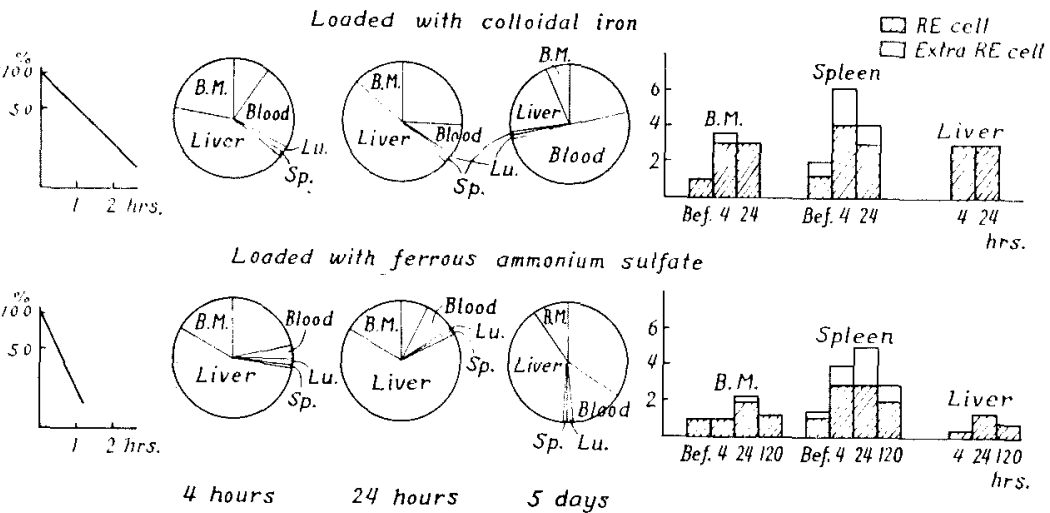

Fig. 3. Iron distribution after the injection of a large dose $(20 \mathrm{mg} / \mathrm{kg})$ of iron in normal rabbits.
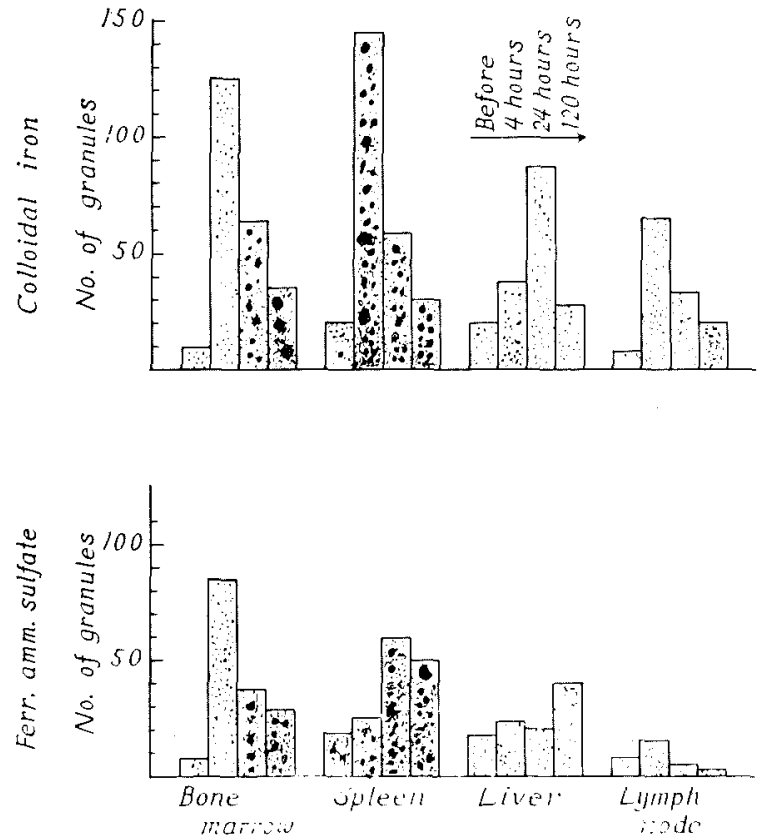

Fig. 4. Hemosiderin granules in RE cell in normal rabbits.

cell of the bone marrow and of the spleen was less than that in the cuses of colloidal iron injection. The turnover of the iron granules in the reticulum cell was slower than that of colloidal iron. In the liver, the amount of iron in the Kupfler cell was less, while the ${ }^{59} \mathrm{Fe}$ activity per unit weight was very high, which showed that the parenchymal cell in the liver played a chief role in the iron deposition in 
TABLE 2. Bone marrow iron (normal rabbits)

Colloidal iron

\begin{tabular}{|c|c|c|c|c|c|c|}
\hline & & & Before & $4 \mathrm{hrs}$ & $24 \mathrm{hrs}$ & 5 days \\
\hline & al t & $\mathrm{Ee}$ & + & 册 & H & H \\
\hline & thre & agocytosis & + & + & - & + \\
\hline & use & e stain & - & - & - & - \\
\hline & & sellular hem. & \pm & 册 & \# & H \\
\hline & & $0 \sim 0.85 \mu$ & 88 & 85 & 51 & 65 \\
\hline & & $0.86 \sim 1.70 \mu$ & 10 & 15 & 42 & 29 \\
\hline 吾 & 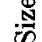 & $1.71 \sim 2.55 \mu$ & 2 & 0 & 5 & 4 \\
\hline$\vec{n}$ & & $2.56 \sim 3.40 \mu$ & 0 & 0 & 2 & 2 \\
\hline$\exists$ & & $3.41 \sim 4.25 \mu$ & 0 & 0 & 0 & $\mathbf{0}$ \\
\hline & & Granulation & + & + & + & + \\
\hline & ह & Irregularity & - & - & - & - \\
\hline & $E$ & Aggregation & - & - & \pm & 4 \\
\hline
\end{tabular}

Ferrous amm. sulfate

\begin{tabular}{|c|c|c|c|c|c|c|}
\hline & & & Before & $4 \mathrm{hrs}$ & $24 \mathrm{hrs}$ & 5 days \\
\hline & $\mathrm{t}$ & $\mathrm{Fe}$ & + & + & $H$ & $\mu$ \\
\hline & thr & agocytosis & \pm & + & + & - \\
\hline & use & de stain & - & - & - & - \\
\hline & & ellular hem. & + & 册 & H & H \\
\hline & & $0 \quad \sim 0.85 \mu$ & 88 & 86 & 62 & 52 \\
\hline 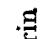 & & $0.86 \sim 1.70 \mu$ & 10 & 14 & 31 & 31 \\
\hline 象 & 赵 & $1.71 \sim 2.55 \mu$ & 2 & 0 & 7 & 16 \\
\hline 2 & & $2.56-3.40 \mu$ & 0 & 0 & $\mathbf{0}$ & 1 \\
\hline ] & & $3.41 \sim 4.25 \mu$ & 0 & 0 & 0 & 0 \\
\hline & & Granulation & + & + & + & + \\
\hline & 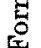 & Irregularity & - & - & - & - \\
\hline & & Aggregation & - & - & + & \pm \\
\hline
\end{tabular}

this case.

Phenylhydrazine treated rabbits: The total amount of iron in the reticulum cell was markedly increased and attained 10-20 times of that in the normal control already before iron injection. The disappearance of ${ }^{59} \mathrm{Fe}$ activity and the amount of iron in reticulum cells were very rapid compared with that of normal rabbits after the injection either of colloidal iron or Mohr's salt (Fig. 5). The amount of iron in reticulum cells was much less at 240 hours after the iron administration than before injection. Vigorous erythrophagocytosis was seen in the bone marrow reticulum cell as well as marked erythroid hyperplasia. Diffuse blue staining was observed in the reticulum cell of bone marrow, spleen and liver, and large 

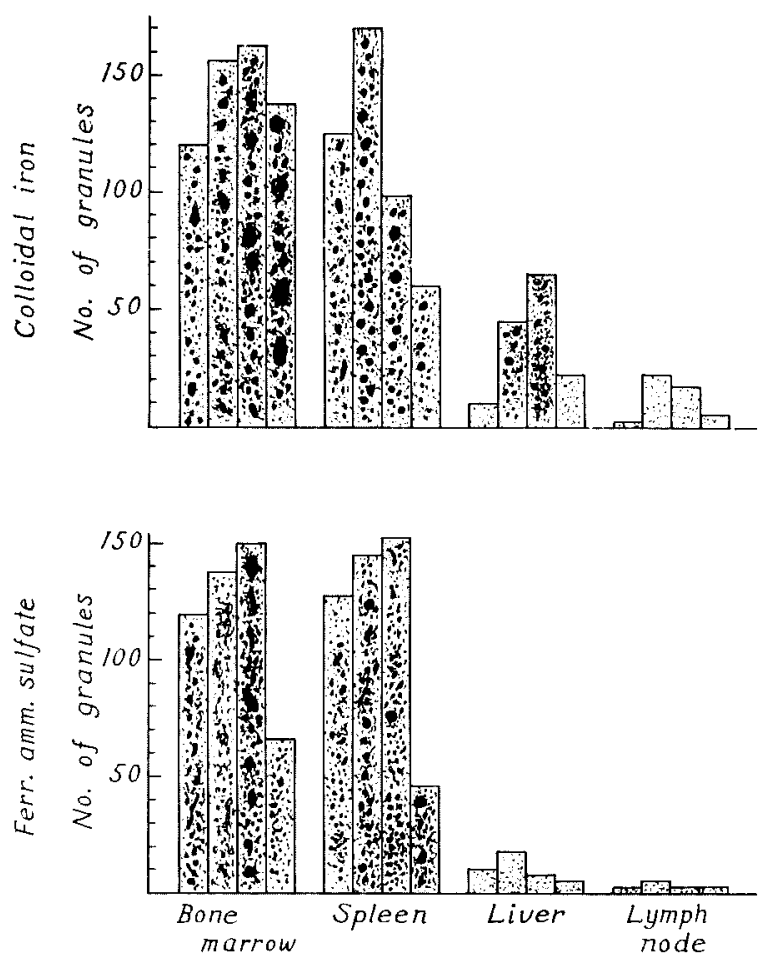

Fig. 5. Hemosiderin granules in RE cell in phenylhydrazine treated rabbits.

irregular-shaped granules were also recognzied.

Lead poisoned rabbits: The amount of iron in reticulum cells in the bone marrow of lead poisoned rabbits was 6 or 7 times higher than that of normal rabbits before iron administration (Fig. 6). After the injection of colloidal iron ${ }^{59} \mathrm{Fe}$, decrease of ${ }^{59} \mathrm{Fe}$ activity in the bone marrow was very slow and the incorporation of ${ }^{59} \mathrm{Fe}$ into red blood cells was also very low on the 5th day. The turnover of radioiron, both of stainable intracytoplasmic and tissue iron was very slow. Diffuse blue staining and aggregation of small spherical granules were observed in the reticulum cells. These findings suggest that production and mobilization of hemosiderin in reticulum cells are abnormal in lead poisoned rabbits.

$X$-ray irradiated rabbit: The amount of stainable iron in the reticulum cell of the bone marrow was 3 times as much as that of normal control. The form of granules were irregular but not so large. The granules were aggregated on the 5 th day after the injection of colloidal iron. Irregular, large and club-shaped granules were found in the bone marrow reticulum cells on the 5th day of the injection of colloidal iron. Irregular, large and club-shaped granules were found 
TABLE 3. Bone marrow iron (phenylhydrazine trented rabbits) Colloidal iron

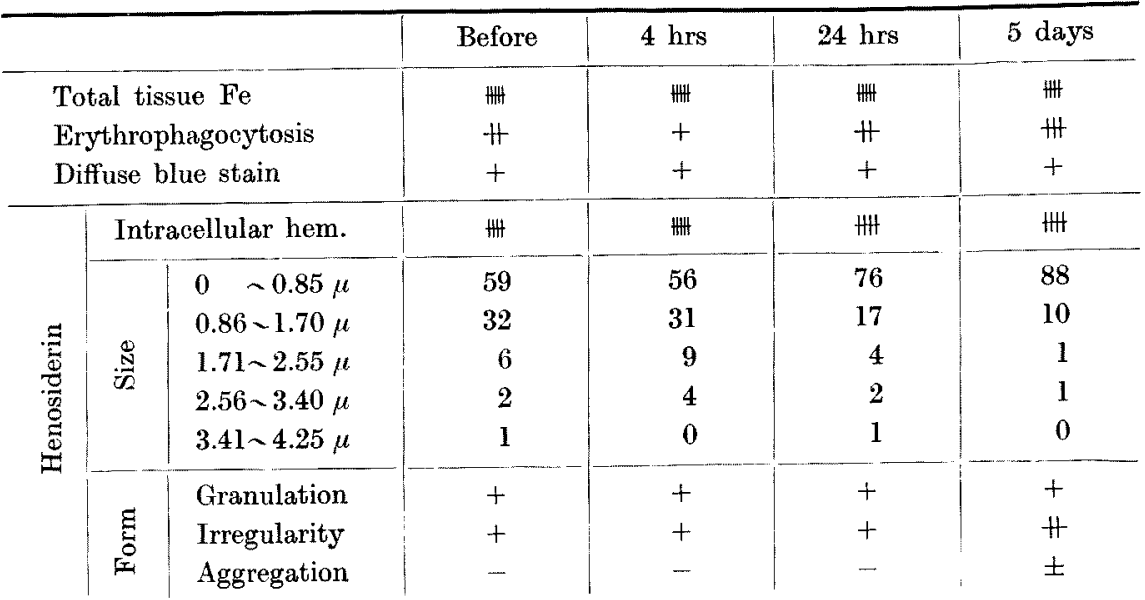

Ferrous amm. sulfate

\begin{tabular}{|c|c|c|c|c|c|c|}
\hline & & & Before & $4 \mathrm{hrs}$ & 24 hrs & 5 days \\
\hline \multirow{3}{*}{\multicolumn{3}{|c|}{$\begin{array}{l}\text { Total tissue Fe } \\
\text { Erythrophogocytosis } \\
\text { Diffuse blue stain }\end{array}$}} & H\#t & H & H & + \\
\hline & & & H & + & H & + \\
\hline & & & + & + & + & + \\
\hline \multirow{9}{*}{ 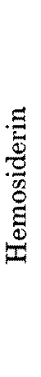 } & \multicolumn{2}{|c|}{ Intracellular hem. } & $H$ & 册 & 册 & $H$ \\
\hline & \multirow{5}{*}{ 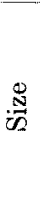 } & $0 \sim 0.85 \mu$ & 59 & 92 & 62 & 87 \\
\hline & & $0.86 \sim 1.70 \mu$ & 32 & 6 & 27 & 9 \\
\hline & & $1.71 \sim 2.55 \mu$ & 6 & 2 & 8 & 4 \\
\hline & & $2.56-3.40 \mu$ & 2 & 0 & 2 & 0 \\
\hline & & $3.41-4.25 \mu$ & 1 & 0 & 1 & 0 \\
\hline & \multirow{3}{*}{ E } & Granulation & + & + & + & + \\
\hline & & Irregularity & + & - & H & \pm \\
\hline & & Aggregation & - & - & \pm & - \\
\hline
\end{tabular}

in the bone marrow reticulum cells on the 5th day of the injection of Mohr's salt. These may suggest that there is an abnormality of hemosiderin formation in $\mathrm{X}$-ray irradiated rabbits.

$E$. coli treated rabbits: The amount of stainable iron in reticulum cells was as much as that of rabbits with lead poisoning. The erythrophagocytosis was recognized in a very high degree in reticulum cells. That may be a cause of iron increase in reticulum cells. The ability of uptake of ${ }^{59} \mathrm{Fe}$ colloidal iron was very low compared with the normal control but the disappearance of ${ }^{59} \mathrm{Fe}$ activity from the bone marrow and incorporation rates of ${ }^{59} \mathrm{Fe}$ in red cells were moderately enhanced. 

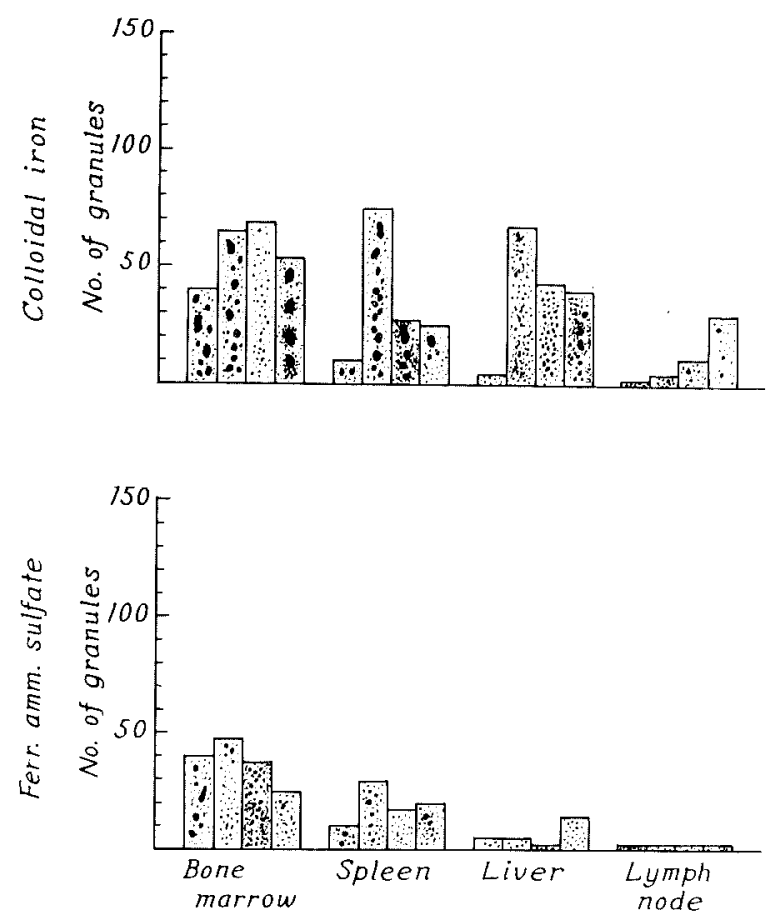

Fig. 6. Hemosiderin granules in RE cell in lead poisoned rabbits.

Phlebotomized rabbits: The ${ }^{59} \mathrm{Fe}$ activity in the bone marrow was very high 4 hours after the injection of colloidal iron ${ }^{59} \mathrm{Fe}$, then it decreased rapidly at 24 hours and 120 hours. The amount of stainable iron in reticulum cells was observed 6 times as much as that of the normal control 4 hours after the injection of colloidal iron, then it disappeared quickly (Fig. 7). However, diffuse blue staining and aggregation of granules were seen in the reticulum cell at 24 hours and 120 hours. The fine granules in the bone marrow reticulum cell disappeared rapidly after the injection of Mohr's salt. Erythrophagocytosis was observed in rabbits subjected to bleeding, the iron turnover in the reticulum cell was very rapid, and iron in the cell seemed to be increased actively as a consequence of the bone marrow hemolysis. The results obtained are summarized as follows:

1) When remainder iron was still present in the reticulum cell after most of administered iron was utilized to hemoglobin synthesis in normal erythropoiesis, iron granules started to aggregate and then they became larger particles which formed a complete sphere.

2) In the cases of phenylhydrazine hemolysis, large irregular-shaped granules appeared on account of conspicuously increased turnover of iron in reticulum cells which came from increased uptake of hemoglobin iron given by 
TABLE 4. Bone marrow iron (lead poisoned rabbits)

Colloidal iron

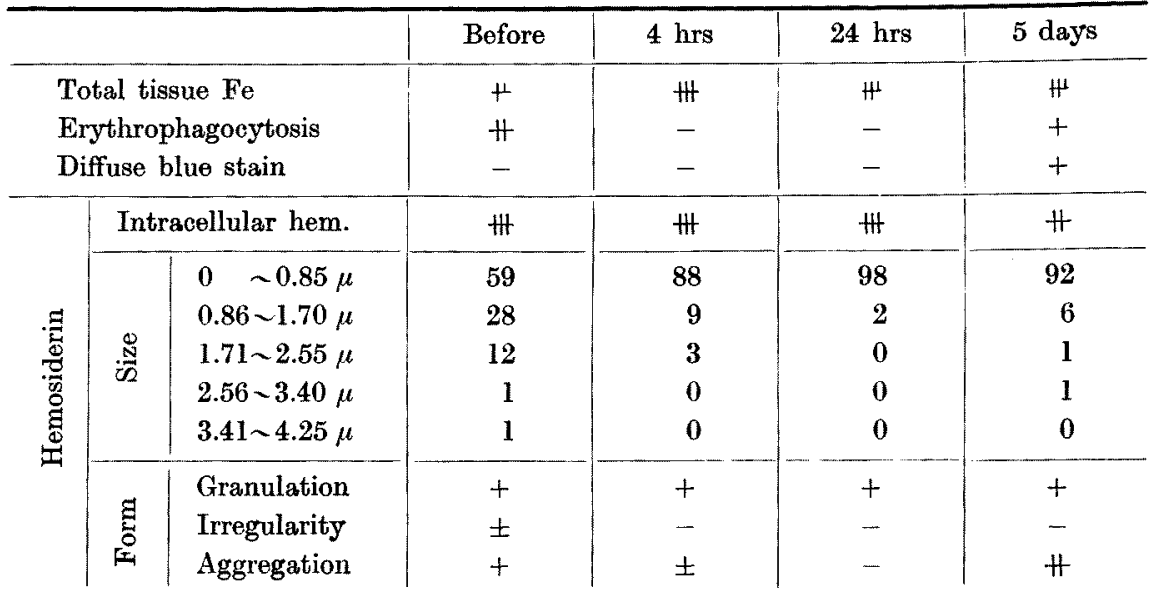

Ferrous amm. sulfate

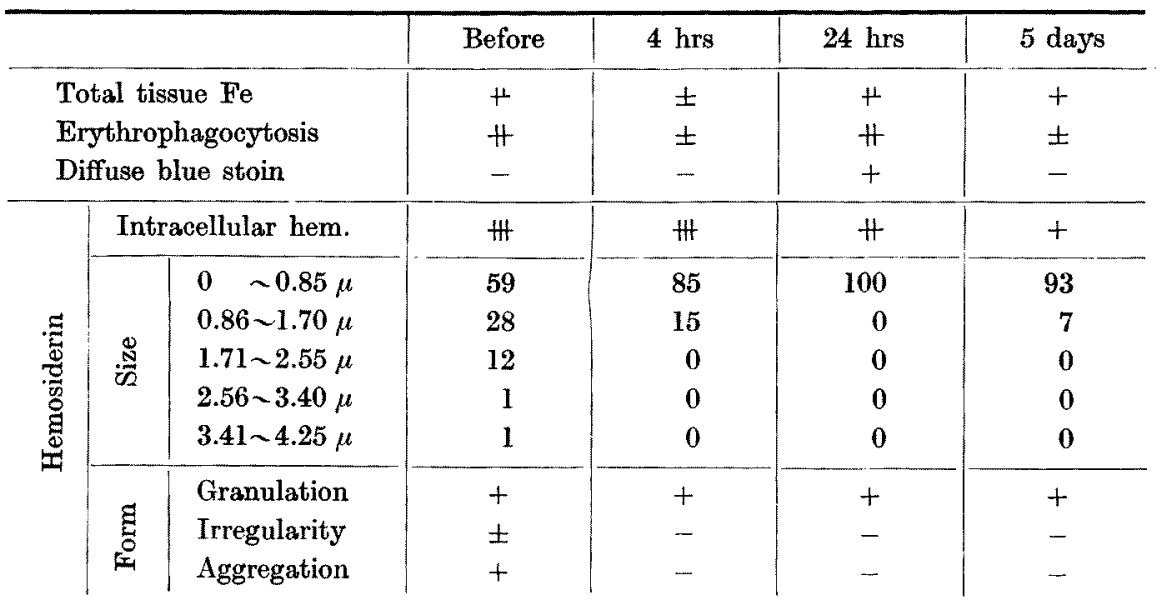

hemolysis, enhanced uptake of colloidal iron and increased excretion of storage iron from the cell.

3) In the cases of lead poisoning, iron granules showed a tendency toward aggregation before iron administration and depressed iron turnover in the reticulum cell after the injection of colloidal iron.

4) The club-shaped iron granules with irregular margins were seen in $x$ ray irradiated rabbits. The reason for the above results are considered to be lowered ability of hemosiderin formation.

5) In the E. coli treated cases, the uptake of colloidal iron was slow but the 

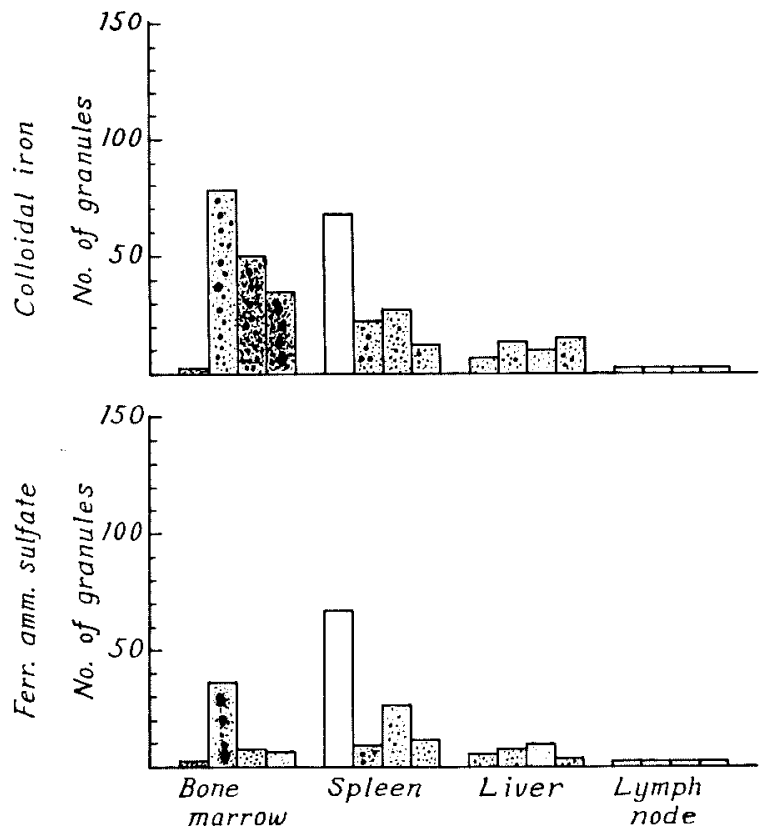

Fig. 7. Hemosiderin granules in RE cell in phlebotomized-rabbits.

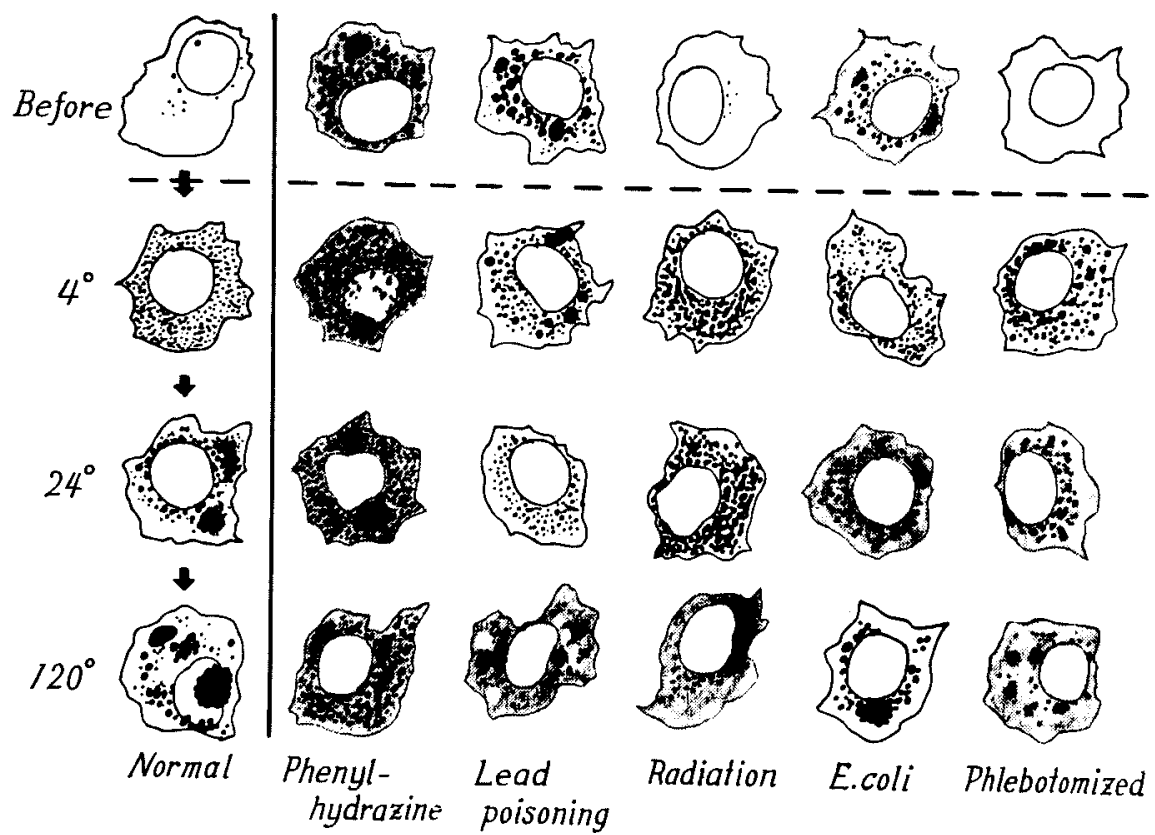

Fig. 8. Changes of hemosiderin granules in bone marrow RE cell after the injection of colloidal iron. 
TABLE 5. Bone marrow iron (phlebotomized rabbits)

Colloidal iron

\begin{tabular}{|c|c|c|c|c|c|c|}
\hline & & & Before & $4 \mathrm{hrs}$ & $24 \mathrm{hrs}$ & 5 days \\
\hline & al & $\mathrm{Fe}$ & \pm & m & \# & \# \\
\hline & thr & agocytosis & H & + & H & H \\
\hline & use & de stain & + & - & + & + \\
\hline & & ellular hem. & \pm & 料 & 世 & $H$ \\
\hline & & $0 \quad-0.85 \mu$ & 91 & 66 & 66 & 97 \\
\hline & & $0.86 \sim 1.70 \mu$ & 9 & 31 & 30 & 3 \\
\hline 悥 & $\stackrel{\mathscr{N}}{\mathscr{N}}$ & $1.71-2.55 \mu$ & 0 & 3 & 4 & 0 \\
\hline \% & & $2.56 \sim 3.40 \mu$ & 0 & 0 & 0 & 0 \\
\hline हु్ㄹ & & $3.41-4.25 \mu$ & 0 & 0 & 0 & 0 \\
\hline & & Granulation & + & + & + & + \\
\hline & है & Irregularity & \pm & + & H & \pm \\
\hline & $\theta$ & Aggregation & - & + & - & - \\
\hline
\end{tabular}

Ferrous amm. sulfate

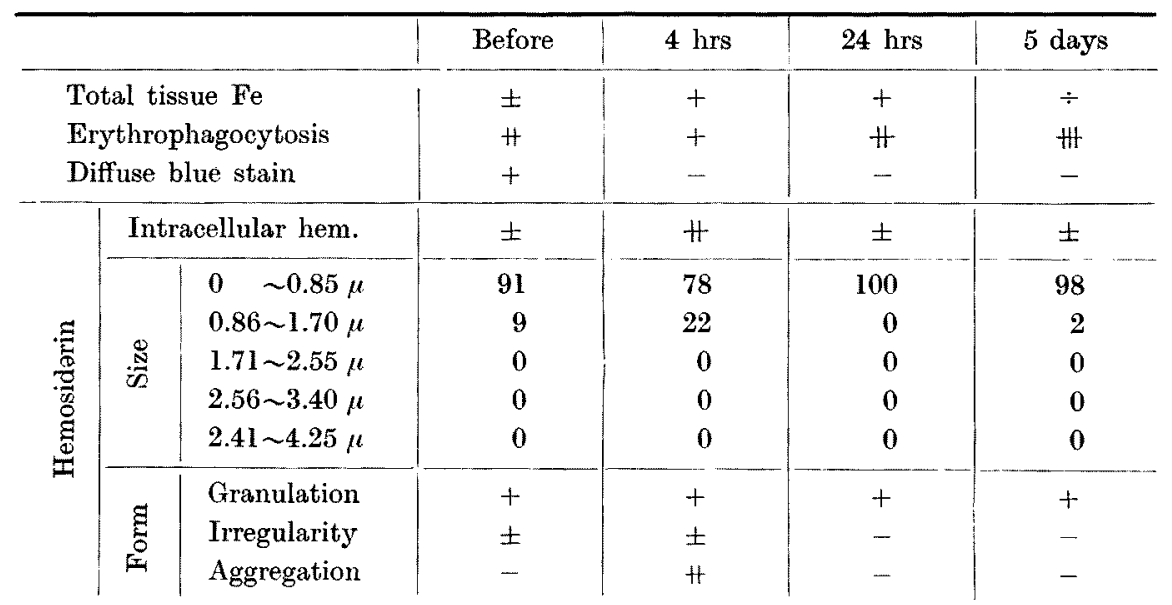

outflow of iron from the cell was moderately rapid.

6) Tremendously increased turnover of hemosiderin was seen in phlebotomized case, because of the increased uptake of colloidal iron to reticulum cells and enhanced iron requirement by accelerated erythropoiesis.

7) When iron outflow was enhanced or iron deposition was increased temporarily in the reticulum cell, diffuse blue staining was observed in the cell. This finding is considered to be a process of granule formation from unstainable ferritin.

8) The amount of iron in the bone marrow reticulum cell, and the forms of hemosiderin granules were essentially influenced by erythrophagocytosis. 


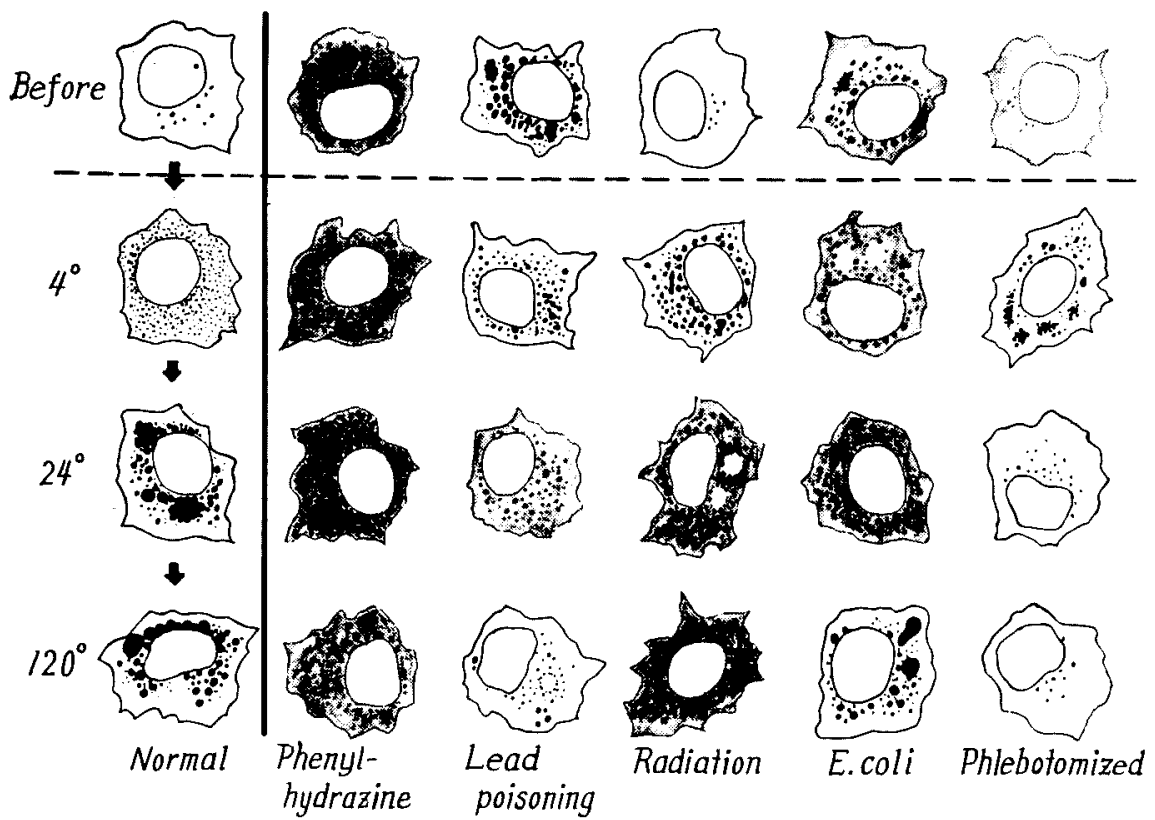

Fig. 9. Changes of hemosiderin granules in bone marrow RE cell after the injection of ferrous ammonium sulfate.

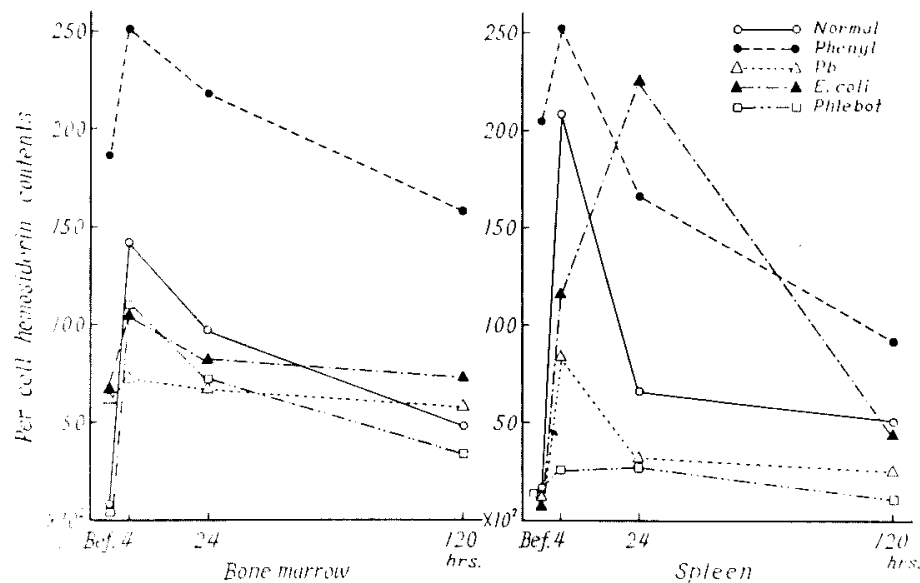

Fig. 10. Changes of hemosiderin contents in RE cell of bone marrow and spleen after the injecton of colloidal iron.

\section{DISCUSSION}

There are many reports ${ }^{2-9}$ concerning histological observations of iron granules in reticulum cells. The amount of stainable iron in reticulum cells were 
classified into 6 classes of 0 to $6+$ in various hematological disorders by Rath and Finch. ${ }^{3}$

However, there are only $a$ few reports on the morphological studies of hemosiderin granules. Beutler ${ }^{10}$ stated that the stainable iron granules in the bone marrow of hemochromatosis were homogeneous mass or crystal-formed. Wallerstein and Pollycove ${ }^{11}$ reported that the granules were fine and homogeneous in pernicious anemia; they were large and irregular in hypoplastic anemia and were not uniform in size in hemolytic anemia.

The same findings were seen in our observations. Besides, diffuse homogeneous blue staining of the cytoplasm of the reticulum cell in the cases of hypoplastic anemia, refractory anemia and hemolytic anemia were observed. From our animal experiments, this blue staining was also observed when iron release or deposition was enhanced in reticulum cells. This condition suggested that the aggregation of ferritin occurred before hemosiderin formation ${ }^{12}$ to a state visible by prussian blue stain. When a large dose of iron was administered, intake of iron in reticulum cells increased, ferritin was aggregated, fine hemosiderin granules appeared and then large homogeneous mass of granules were formed in the normal case. However, if a metabolic disturbance in the reticulum cell was present, clubor comma-shaped irregular granules were seen in the cell due to the disturbance of hemosiderin formation. A semiquantitative analysis was performed on the amount of iron in reticulum cells and sideroblasts of the bone marrow. The expression of the iron content was described before. The amount of iron in reticulum cells of the bone marrow and in sideroblasts was moderately correlated. Bessis $^{13}$ showed in his electronmicrogram that ferritin was transferred directly from the cytoplasm of the reticulum cell to erythroblasts. Weinfeld ${ }^{14}$ studied the $^{-}$ relationship between the sideroblast count and serum iron value or saturation grade of transferrin and considered that iron in erythroblasts might be supplied not only from plasma transferrin but also directly from ferritin in reticulum cells of the bone marrow in certain hematological disorders such as anemia due to infection. However, it is rather probable that the above correlation is only an apparent one and does not necessarily indicate the asserted sequence of processes. The amount of iron in both reticulum cells and sideroblasts correlated well to erythropoiesis which was expressed as the utilization rate of administered radioiron in red cells. Colloidal iron was chiefly taken to Kupffer cells in the liver after intravenous injection ${ }^{15}$, but in our experiment in which a large dose of colloidal iron was administered, it was also taken by the reticulum cell of the spleen and bone marrow in a colloidal form. Then colloidal iron was opsonized in the cell, iron was released from the binder and entered the plasma as plasma iron. So the behavior of iron granules in the reticulum cell after the injection of colloidal iron is related to the iron turnover in the cytoplasm of the cell.

In our cases, Mohr's salt was taken in the parenchymal cell of the liver after 
the injection of its large dose, because the iron content of the plasma at that time far exceeded the iron binding capacity of the plasma. After that, iron in the parenchymal cell disappeared gradually from the cell and re-entered the plasma. During several hours after the injection of Mohr's salt, plasma transferrin was saturated. So, the changes of iron granules in the reticulum cell in this condition was considered to indicate a storage deposition from saturated transferrin at the first stage and the release of iron from the cell at the second stage. The specific activity of ${ }^{59} \mathrm{Fe}$ in the liver was higher than that in the spleen and bone marrow after the injection of Mohr's salt. But iron granules in Kupffer cells were markedly less than those in the reticulum cells of the spleen and bone marrow. More iron granules in parenchymal cell in the liver were observed than those in the case of colloidal iron injection, although they were not so abundant.

Hemosiderin turnover in the reticulum cell of the spleen was more rapid than that of the bone marrow within 24 hours after colloidal iron injection but it became markedly slower after that period. Hemosiderin turnover rate in the bone marrow reticulum cell was approximately expressed by an exponential function until 120 hours with the half time of 19 hours. The turnover rate in the phenylhydrazine treated group was similar to that in normal control, however, that in E. coli treated and lead poisoned groups were markedly slower than in normal ones. It was suggested that there was a disturbance of iron mobilization from reticulum cells in cases of $\mathrm{E}$. coli treated and lead poisoned rabbits. It was also suggested that the ability of storage iron turnover in the spleen reticulum cell was different from that in the bone marrow.

The phagocytosis of erythroblasts by the bone marrow reticulum cell was observed in various hematological disorders such as pernicious, iron deficiency, hemolytic and hypoplastic anemias.

It might be a histological proof of the ineffective erythropoiesis which was stated by a number of authors ${ }^{16-18}$ studying iron and bilirubin metabolism. On the other hand, phagocytosis of erythrocytes in the reticulum cell was often seen in the above diseases and also in animal experiments especially in the phlebotomized and phenylhydrazine treated groups. Marked erythrophagocytosis was observed in the animals after the injection of heated nonviable red cells. From these findings, it was considered that the amount of iron in the bone marrow reticulum cell was partially influenced by hemoglobin iron produced by erythrophagocytosis, and the reticulum cell in the bone marrow played some role in the destruction of peripheral red cells.

\section{Acknowledgment}

The authors wish to express thanks to Professor G. Wakisaka for his kindly guidance; to Professor M. Hanaoka, the Department of Pathology in Virus Research Laboratory, Kyoto University, for his valuable suggestion, and to our co-workers for their assistance throughout this work. 


\section{References}

1) Kaplan, E., Zuelzer, W.W. \& Mouriquand, C. Sideroblasts. A study of stainable nonhemoglobin iron in marrow normoblasts. Blood, 1954, 9, 203-213.

2) Finch, C.A., Hegsted, M., Kinney, T.D., Thomas, E.D., Rath, C.E., Haskins, D., Finch, S. \& Fluhartz, R.G. Iron metabolism: Pathophysiology of iron storage. Blood, 1950, 5, 983-1008.

3) Rath, C.E. \& Finch, C.A. Sternal marrow hemosiderin. Method for determination of available iron stores in man. J. Lab. clin. Med., 1948, 33, 81-86.

4) Stevens, A.R., Jr., Coleman, D.H. \& Finch, C.A. Iron metabolism: Clinical evaluation of iron stores. Ann. int. Med., 1953, 38, 199-205.

5) Davidson, W.M. \& Jennison, R.F. Relationship between iron storage and anaemia. J. clin. Path., 1952, 5. 281-285.

6) Beutler, E., Drennan, W. \& Block, M. Bone marrow and liver in iron deficiency anemia: Histopathologic study of sections with special reference to stainable iron content. J. Lab. clin. Med., 1954, 43, 427-439.

7) Hutchinson, H.E. Significance of stainable iron in sternal marrow sections; its applciation in control of iron therapy. Blood, 1953, 8, 236-248.

8) Wallerstein, R.O. Bone marrow hemosiderin in infants and children. J. Amer. Med. Women's Ass., 1954, 9, 149-150.

9) Wallerstein, R.O. \& Aggeler, P.M. Anemia: Differentiating between thalassemin minor and iron deficiency. California Med., 1956, 84, 176-179.

10) Beutler, E. Clincial evaluation of iron stores. New Engl. J. Med., 1957, 256, 692697.

11) Wallerstein, R.O. \& Pollycove, M. Bone marrow hemosiderin and ferrokinetic patterns in anemia. 1. Pernicious anemia. A.M.A. Arch. int. Med., 1958, 101, 418424.

12) Sturgeon, P. \& Shoden, A. Mechanisms of iron storage. In: Iron Metabolsim. An International Symposium, edited by F. Gross, Springer-Verlag, Berlin, 1964, p. 121.

13) Bessis, M. Etude au microscope électronique du rôle de la ferritine dans le cycle hemoglobinique du fer. In: Eisenstoffuechsel, edited by W. Keiderling, Georg Thience Verlag, Stuttgart, 1959, p. 11.

14) Weinfeld, A. Storage iron in man. Acta med. Scand., 1964, 177, Suppl., 427.

15) Wakisaka, G. \& Kariyone, S. A study of the RES function using colloidal iron and heated nonviable cell. Proc. IVth intern. Sympo. of RES, 1964, 445.

16) Pollycove, M. Ferrokinetics, techniques. In: Eisenstoffwechsel, Georg Thieme Verlag, Stuttgart, 1959, p. 20.

17) London, I.M., Shemin, D., West, R. \& Rittenberg, D. Heme synthesis and red blood cell dynamics in normal humans and in subjects with polycythemia vera, sickle cell anemia, and pernicious anemia. J. biol. Chem., 1949, 179, 463-484.

18) Finch, C.A., Coleman, D.H., Motulsky, A.G., Donohue, D.M. \& Reiff, R.H. Erythrokinetics in pernicious anemia. Blood, 1956, 11, 807-820. 


\section{Explanations for Figs. 11-22}

Reticulum cells in the bone marrow under high manification $(\star 1,000)$. Fig. 11 Fig. 20, stained by Kaplan's method. Fig. 21 and Fig. 22, vital stained with carmine and stained with ordinary hematoxylin.

Fig. 11. Pernicious anemia. 56y. Male. Many fine cytoplasmic hemosiderin granules are of almost the same size, less than $0.85 \mu$ in diameter. Average count of granules per cell is 43.1 in contrast with the normal. A phagocytized erythrocyte is seen in the upper right part of the reticulum cell.

Fig. 12. Aplastic anemia. 18y. Male. Large hemosiderin granules, more than $1.70 \mu$ in diameter, are seen in the cytoplasm. The shape and margin of the granules are irregular. They are aggregated and clumped. Average count of granules per cell is 37 to 44.4 . Homogeneous blue staining of the cytoplasm is seen.

Fig. 13. Congenital spherocytic hemolytic anemia. 23y. Male. Coarse and irregular hemosiderin granules more than $3.4 \mu$ in diameter are seen in the cytoplasm. Average count of granules per cell is 51.8 to 69.0 , and diffuse blue staining of the cytoplasm is distinct.

Fig. 14. Refractory anemia. 21y. Female. Coarse and granular hemosiderin scattered in the cytoplasm, and average count of the granules per cell is low and about 8.5. However, homogeneous diffuse blue staining of the cytoplasm is very intense.

Fig. 15. Normal rabbit 4 hrs after administration of a large dose of colloidal iron. Many small hemosiderin granules, about 120 per cell, are seen in the cytoplasm. They are about $l \mu$ in diameter.

Fig. 16. The same animal after $120 \mathrm{hrs}$. Average count of cytoplasmic hemosiderin granules is reduced, while the size is increased to $3.4 \mu$ in diameter, suggesting aggregation and clumping of granules.

Fig. 17. Phenylhydrazine treated rabbit 4 hrs after administration of colloidal iron. Coarse and large irregular hemosiderin granules about $3.4 \mu$ in diameter are seen in cytoplasm in a large number. Homogeneous diffuse blue staining of cytoplasm is distinct.

Fig. 18. Lead-poisoned rabbit 5 days after administration with colloidal iron. Intracellular hemosiderin granules are decreased, and cytoplasmic blue staining is increased. At arrow points relatively small granules aggregated and clumped together.

Fig. 19. Irradiated rabbit 5 days after the administration of Mohr's salt. Coarse and large irregular hemosiderin granules, which are of peculiar shapes, sometimes rodlike or comma-shaped, are seen in the cytoplasm. They are about $4.0 \mu$ in diameter and are aggregated. Cytoplasmic blue staining is very distinct.

Fig. 20. Liver cells and Kupffer cells of an E. coli treated rabbit 4 hrs after the administration of Mohr's salt. Numerous fine and light blue stained granules are seen in liver cells (at arrow points), while in Kupffer cells (at the right upper corner and to the left), hemosiderin granules are very few in number. 
Fig. 21. Phlebotomized rabbit 5 days after the administration of colloidal iron. At arrow points, two erythrocytes are phagocytized and subject to digestion.

Fig. 22. Non-viable red cell injected rabbit, $24 \mathrm{hrs}$ after the administration. At arrow points, an erythroblast and two erythrocytes are phagocytized and subject to digestion. 


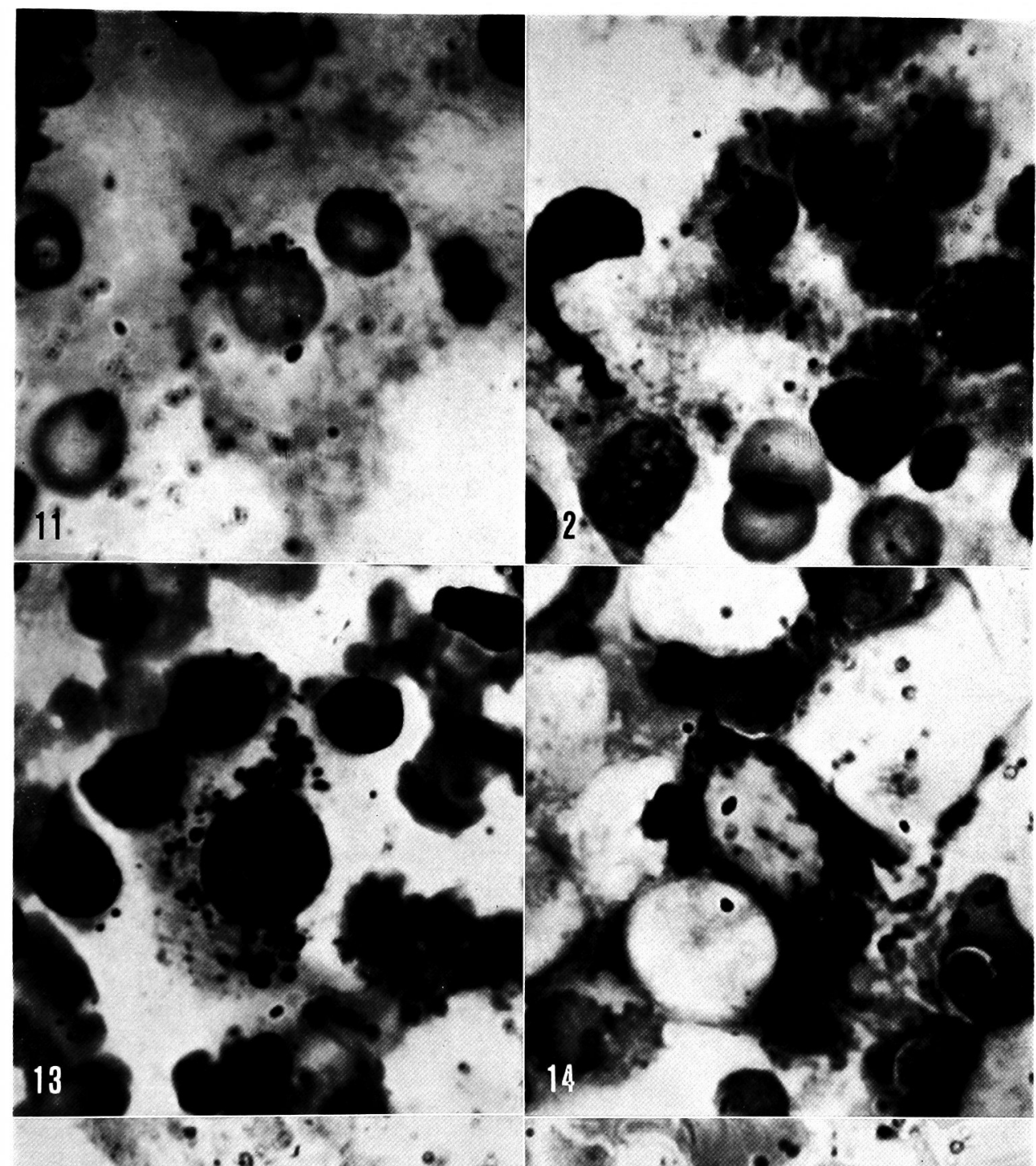

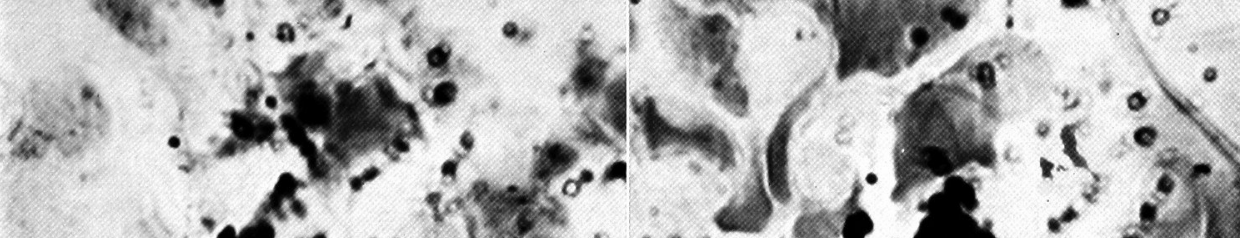

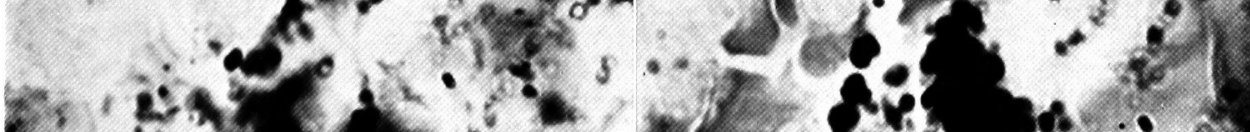

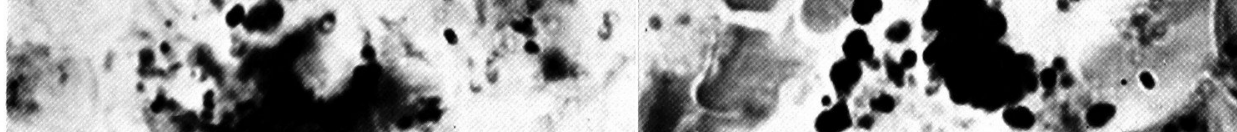
4.t.t.

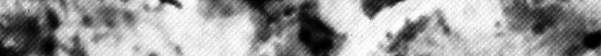

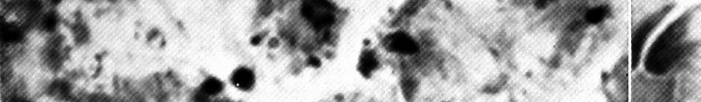
$15=20^{2}{ }^{2}+1 \%$ एक 16

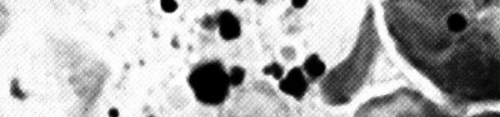




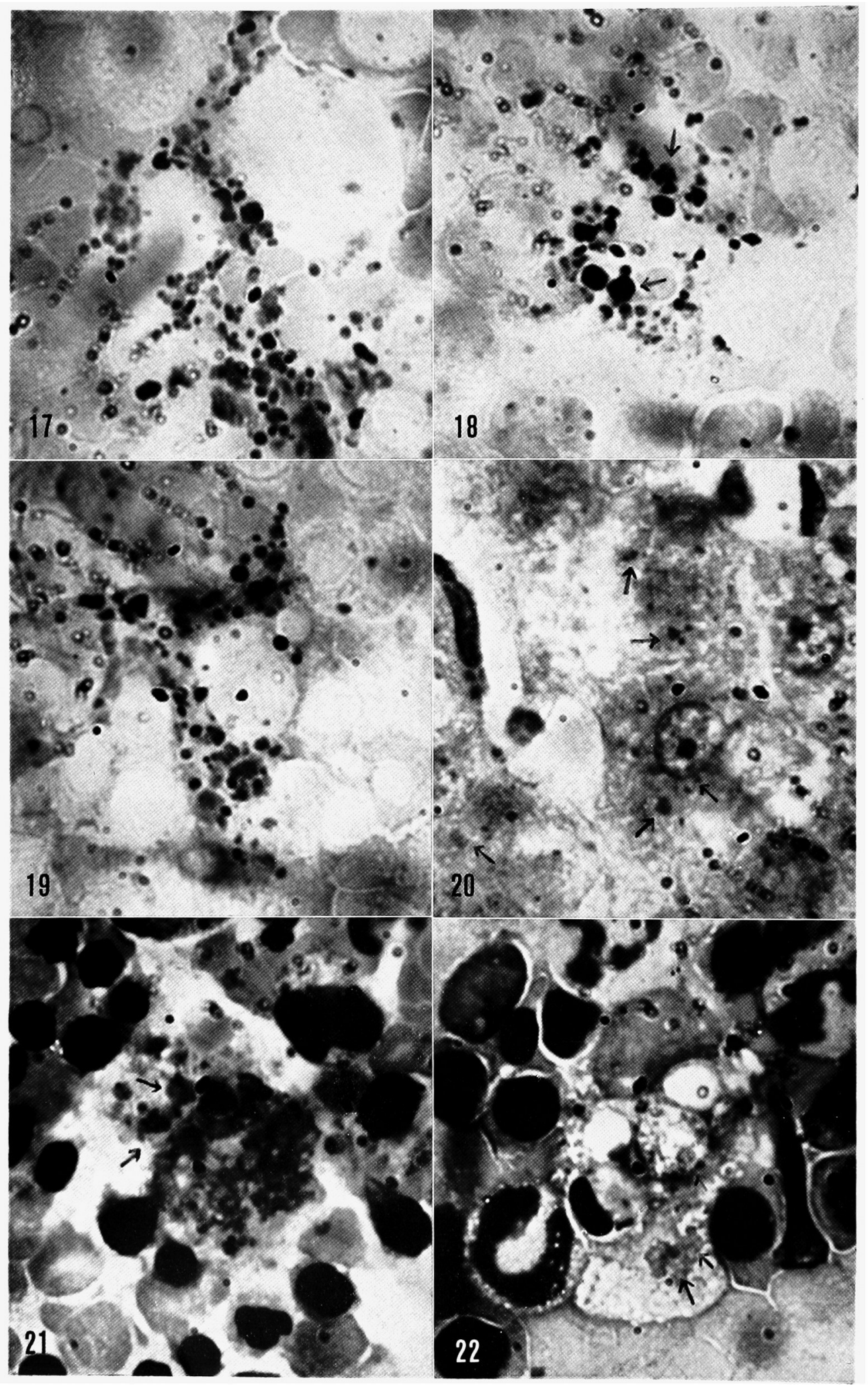

